\title{
HOTS questioning ability and HOTS perception of language teachers in Indonesia
}

\author{
Imelda Gozali ${ }^{1}$, Anita Lie ${ }^{1}$, Siti Mina Tamah ${ }^{1}$, and Fransiskus Jemadi ${ }^{2}$ \\ ${ }^{I}$ English Education Study Program, Faculty of Teacher Training and Education, \\ Universitas Katolik Widya Mandala Surabaya, Jalan Kalijudan no. 37, Surabaya, Indonesia \\ ${ }^{2}$ English Education Study Program, Faculty of Teacher Training and Education, \\ Universitas Katolik Indonesia Santu Paulus Ruteng, Manggarai, East Nusa Tenggara, Indonesia
}

\begin{tabular}{|c|c|}
\hline $\begin{array}{l}\text { ABSTRACT } \\
\text { This study is part of a larger-scale research aimed at ma } \\
\text { teachers of English and Indonesian Language across t } \\
\text { features in Indonesia. As a subset of the study, this paper } \\
\text { formulate higher-order thinking (HOT) questions in the c } \\
\text { as getting their perception about applying HOTS in thei } \\
\text { comparing the abilities across teachers' regions, years of } \\
\text { and Indonesian Language). This research was designed a } \\
\text { and qualitative data analyses, with } 15 \text { (fifteen) secondar } \\
\text { Data were collected through classroom observations, doc } \\
\text { as teachers' interviews. Quantitative analysis was pe } \\
\text { formulating HOTS questions, while teaching docume } \\
\text { qualitative analysis. Although the statistical results revea } \\
\text { the HOTS questioning scores of the teachers in the di } \\
\text { qualitative data suggested that language medium, as shov } \\
\text { and Indonesian Language teachers, might be an impor } \\
\text { teachers to ask HOT questions, as well as their perception } \\
\text { classes. The inquiry into the teachers' perceptions of } \\
\text { teachers in the bigger city and those in more remote regior } \\
\text { the practitioners. }\end{array}$ & $\begin{array}{l}\text { the pedagogical competence of } \\
\text { ities of differing demographic } \\
\mathrm{d} \text { on investigating the ability to } \\
\mathrm{m} \text { among the teachers, as well } \\
\text { es. The mapping was done by } \\
\text { e, and subjects taught (English } \\
\text { se study involving quantitative } \\
\text { ol teachers as the participants. } \\
\text { (lesson plan) analyses, as well } \\
\mathrm{d} \text { on the teachers' scores in } \\
\mathrm{d} \text { transcripts were coded for } \\
\text { significant difference between } \\
\text { regions and years of service, } \\
\text { the difference between English } \\
\text { actor affecting the abilities of } \\
\text { applicability of HOTS in their } \\
\text { also displayed a gap between } \\
\text { vell as between the novices and }\end{array}$ \\
\hline $\begin{array}{l}\text { Keywords: Critical thinking; Higher-Order Thinking } \\
\text { pedagogical competence; questioning skills; }\end{array}$ & $\begin{array}{l}\text { (HOTS); language teachers; } \\
\text { professional development }\end{array}$ \\
\hline $\begin{array}{cc}\text { First Received: } & \text { Revised: } \\
\text { 7 July 2020 } & \text { 19 December 2020 } \\
\text { Final Proof Received: } & \\
\text { 26 February 2021 } & \\
\end{array}$ & $\begin{array}{l}\text { Accepted: } \\
\text { 21 January } 2021 \\
\text { Published: } \\
\text { 31 May } 2021 \\
\end{array}$ \\
\hline \multicolumn{2}{|c|}{$\begin{array}{l}\text { How to cite (in APA style): } \\
\text { Gozali, I., Lie, A., Tamah, S. M., \& Jemadi, F. (2021). HOTS questioning ability and HOTS } \\
\text { perception of language teachers in Indonesia. Indonesian Journal of Applied Linguistics, } \\
\text { 11(1), 60-71. https://doi.org/10.17509/ijal.v11i1.34583 }\end{array}$} \\
\hline
\end{tabular}

\section{INTRODUCTION}

The Industrial Revolution 4.0 that has fundamentally been transforming humankind through the new technologies and scientific discoveries requires that people employ critical thinking skills because, with the pervasive adoption of artificial intelligence and robotics leading to automation, people need to acquire skills that are less easy to automate such as creativity and critical thinking so as not to be replaced by machine. In their OECD study involving hundreds of teachers in eleven countries, Vincent-Lancrin et al. (2019) concluded that schools need to nurture students' creativity and critical thinking. Thus, there is a pressing need for countries like Indonesia to equip its citizens with higher order thinking skills so they

\footnotetext{
*Corresponding Author

Email: imelda.gozali@ukwms.ac.id
} 
can survive in the Industrial Revolution 4.0 and contribute to the local communities as well as to the global society. This is especially true for the young segment of the society, the students and the youth, who will be at the helm of the nation's ark, navigating through the $21^{\text {st }}$ century turbulent waters (Lie, 2021). As such, the role of educational institutions, where young people spend most of their time during their formative years, is crucial in instilling the habit of thinking critically in the students (Harjanto et al, 2018). Teachers, therefore, who are at the forefront of the formative battle, are expected to be the role model and guide for the students so as to enable them to possess those important qualities needed to survive in this millennium (World Bank, 2020).

At the national level, this concern has been translated into a ministerial policy in the form of the Ministry of Education and Culture decree entitled Permendikbud (Peraturan Menteri Pendidikan dan Kebudayaan) no. 22, 2016, which stipulated that students should develop critical thinking skills in school, guided by the taxonomy which has been known worldwide bearing the name of its author, Benjamin Bloom. At the lower parts of the pyramid there are knowledge, comprehension, application, which make up the Lower Order Thinking Skills, and then analysis, synthesis, and evaluation which are termed Higher Order Thinking Skills ("HOTS") (Bloom et. al., 1956 in Krathwohl, 2002). Anderson and Krathwohl further developed the taxonomy and thus, HOTS is specified further to be the skill of analyzing, evaluating, and creating knowledge which are conceptual, procedural, and metacognitive (Anderson \& Krathwohl, 2001; Barak \& Judy, 2009)

The current curriculum, termed Kurikulum 2013 or K-13, clearly spells out the requirement for HOTS to be implemented in the classroom. In its latest document issued in 2018, the ruling of the General Secretary of the Ministry of Education and Culture indicated that the Lesson Plan (betterknown locally as Rencana Pelaksanaan Pembelajaran or RPP) of the K-13 curriculum should include the $21^{\text {st }}$ Century Skills namely Critical Thinking, Creativity, Communication and Collaboration (Peraturan Sekretaris Jenderal Kementerian Pendidikan dan Kebudayaan Nomor 7 Tahun 2018 tentang Pedoman Pelatihan Kurikulum 2013 bagi GTK Tahun 2018). Besides, teachers ought to "provide knowledge and skills in the learning practice, provide assessment based on higher-order thinking skills or HOTS, and to review the outcome of the learning practice." (idem). In order to aid the teacher in implementing this curriculum in the classroom, various trainings and workshops are organized by the government, as well as independently through the Teachers Working Group (Musyawarah Guru Mata Pelajaran, or MGMP for short). In 2019, the Directorate General of Teachers and Education Personnel published a series of books intended to guide teachers and teaching staff to deliver HOTS-based teaching and learning, one of which is entitled The Guidebook for HOTS-Oriented Learning ("The Guidebook") (Ariyana et al., 2019)

Within the chapter entitled "Learning Design", The Guidebook describes a way of applying HOTS in the classroom, namely through question formulation during lesson time. Instead of onedirectional, teacher-centered 'lecturing' approach, HOTS-inducing style of questioning is such that it focuses the students on the topics to be covered, encourages students to reason or to take a stand, and to clarify concepts in order to find the right definition. Questions in the classroom are further classified as inferential, interpretative, transfer, and hypothetic. Some case studies were also given in order to help teachers to apply the above types of questioning during lesson time. Lastly, The Guidebook also provides samples of learning activities carried out with questioning techniques being embedded within.

In light of the effort spent by the Indonesian government to enable students to develop their thinking skills as shown by the nation-wide policy, training, and dissemination of manuals as described above, it is of interest to see the extent to which all of the above measures are implemented by the teachers. This study was then conducted across three different cities of Indonesia in order to gauge the abilities of language teachers to formulate HOTS questions in the classroom. Furthermore, the perception of those teachers with regard to formulating HOTS questions in particular and HOTS implementation in the classroom in general were also investigated.

In summary, this study attempts to answer the following questions:

1. Are there differences in the ability to use HOTS-promoting questions across the cities, the different lengths of service, and the language medium among the teachers?

2. Are there differences in the perceptions of the language teachers regarding formulating HOTS questions in particular and HOTS in general?

\section{HOTS in the classroom}

Albeit being criticized as being vague and impractical (Ennis, 1985), Bloom Taxonomy, and its subsequent revision by Anderson and Krathwohl, still proves to be a valuable tool for educational policymakers and practitioners in preparing guidelines and teaching materials, among others. Recent studies showed that educators still strive to devise teaching methodologies and other pedagogical tools to promote Higher-Order Thinking Skills (HOTS) among their students (Jailani et al., 2017; 
Obenchain \& Ives, 2006) while curriculum revision was done so as to incorporate HOTS in students' learning and assessment (Sulaiman et al., 2015). The educators themselves were also trained in their knowledge of HOTS' principles and implementation skills, as several studies testified (Barak \& Judy, 2009; Thompson, 2008).

The original Bloom's taxonomy comprises six cognitive categories, namely Knowledge, Comprehension, Application, Analysis, Synthesis, and Evaluation, going from what is considered to be the lower level of thinking to higher. This was subsequently revised by Anderson and Krathwohl by adding another dimension to the original taxonomy, and thus separating the knowledge dimension from the cognitive process. Under the knowledge dimension, Anderson and Krathwohl identified four levels of knowledge; factual, conceptual, procedural, and metacognitive (Anderson \& Krathwohl, 2001; Miri et al., 2007). While the first three levels were already present in the original Bloom taxonomy, Anderson and Krathwohl added metacognitive knowledge--the knowledge of cognitive strategies and selfcognition--as metacognition was still relatively unknown in those days. For the cognitive process dimension, some of the original categories were retained and some were reordered, while changing all the noun forms of the terminology into verbs. Thus, the revised version consists of Remember, Understand, Apply, Analyze, Evaluate, and Create, going from the least to the most complex (Krathwohl, 2002).

In a meta study compiled from 29 reports around the U.S. and U.K., Brookhart (2010) indicated three benefits of teaching and assessing thinking skills in the classroom. Thinking skills instruction was found to have a strong impact on students' cognitive skills (effect size of 0.62 over 29 studies), curricular outcomes such as in Reading, Math and Science (0.62 over 19 studies) as well as students' attitude and motivation (1.44 over 6 studies). There was also evidence that HOTS instruction benefitted students with educational disadvantages (Pogrow, 2005 in Brookhart, 2010).

While the benefit of teaching higher-order thinking seems indisputable, and the teachers themselves acknowledge its importance (Fischer et al., 2011; Seman et al., 2017), getting students to acquire HOTS in the classroom remains a herculean task. In the first place, teachers as the key players in the teaching-learning process may not have sufficient knowledge and competence in HOTS. In their studies on the challenges teachers faced in teaching and learning HOTS in primary schools in Malaysia, Seman et al. (2017) reported that teachers still have basic, or even mistaken notions about HOTS. They also still struggle to incorporate HOTS in their lesson plan, methodology, and assessment. Several teachers have the perception that teaching
HOTS will lessen the content of the subjects taught or take up more of the lesson time. Not few of the teachers also cited the students' mixed abilities and learning styles as the source of challenge in teaching HOTS; students with lower cognitive competence need more repetition of basic facts, and some students still rely heavily on the teacher as the source of knowledge, and thus finding it hard to think for themselves (Seman et al., 2017). Similar conclusion along this line is also found in Zohar et al. (2001), who stated that most teachers believe that teaching for HOTS is inappropriate for lowachieving students.

Other studies provide further evidence to the challenges in promoting HOTS as described above. Fischer et al. (2011) revealed that insufficient training in promoting critical thinking, as well as inadequate supervision on teachers, contribute to the lack of HOT-promoting teaching behavior. Teachers have difficulties in categorizing their assessment questions in terms of Bloom's taxonomy (Thompson, 2008). A meta-study on the various research on HOTS implementation in Malaysia emphasized the need for TESL student teachers to be sufficiently trained in HOTS (Arumugam et al., 2016).

The educational landscape in Indonesia regarding teachers' perception and skills in implementing HOTS in the classroom seems to present a similar outlook. Teachers felt that they lacked the knowledge and experience to construct HOTS-based questions, were not provided with the necessary learning materials and resources, and were impeded by their students' mixed ability (Prihastuti \& Widodo, 2019; Retnawati et al., 2018; Tyas et al., 2019). A study on the perceptions of HOTS among teachers of different generations (Baby Boomers, X, and Y) revealed that teachers with more experience had more understanding of HOTS and were striving to implement it in the classroom (Mursyid \& Kurniawati, 2019). Nevertheless, English teachers believe in the importance of HOTS and are making attempts to incorporate approaches that promote HOTS in their teaching methodology (Mustika et al., 2019).

\section{Questions in the classroom}

Teaching through questions has been associated with the Greek philosopher Socrates, who developed his lessons by asking questions that encouraged his students to think and express their opinions. It is generally believed that this Socratic method of inquiry makes classroom learning more engaging and memorable (Fahim, 2012). This bi-millennial old method still seems to be applicable even in this $21^{\text {st }}$ century. In a meta-study which reported various researchers dealing with classroom questioning, it has been shown that classroom questioning is linked to students' achievement gain, improved test results, learning enhancement, and better comprehension 
(Cotton, 1988). However, when it comes to relating the cognitive level of the questions with the students' outcome, the results have not been conclusive. Some reported no relation between HOTS questions with learning outcome (Brophy, 1988), while others claimed that asking higher-order questions has been proven by previous researchers to be positively linked to students' gain (Marzano et al., 2001). Nappi (2017) argued that lower order thinking questions such as the 'recall' type is beneficial for acquiring new information, while success in real life is about applying the newfound knowledge in different situations, which requires students to develop the 'application' type of thinking skill.

In language teaching, questions could also be divided into several typologies, for example, Display and Referential (Cundale, 2001). Display question is a type in which the answer is known by the teacher, and he or she simply asks the question to check the students' understanding. The next type of question is termed Referential, in which the teacher does not know the answer and is asking the question in order to elicit a discussion. For example, by asking "Do you think learning English will be useful for your future?" students will have to provide a personal, extended reply using their entire knowledge of English. Cundale then argued that Display questions are more apt to encourage attention to forms and accuracy in language learning, while Referential questions will promote more meaningful conversation and fluency (Cundale, 2001). In his study, Yu (2010) discovered that college English teachers in China used few Referential questions (13.03\%), and thus were mostly asking for what he termed 'pseudoinformation' instead of getting the students to practice speaking extensively in English. Similarly, Tamah (2003) in her studies also found that Display questions were largely employed in an EFL class that she investigated, while the Referential type was much abandoned.

Despite the evidence on the advantage of good questioning strategy in language teaching, the implementation of this skill among teachers is still found wanting. In China, Sun (2012) revealed that EFL students expected their teachers to ask questions that promote language learning in a harmonious and respectful way. Albergaria-Almeida (2010) reported that the Portuguese teacher used more fact-based questions as compared to the Philosophy teacher, despite the reality that one of the aims of language teaching stipulated in the curriculum is to enhance creativity. The abovementioned study in Malaysia by Seman et al. (2017) revealed that most of the teachers were unaware of Socratic questioning nor classroom questioning strategies that promote higher-order thinking.

In Indonesia, studies on types and cognitive level of classroom questioning during language teaching likewise show that more training for educators are needed in this respect. Matra (2014) conducted a research in an English classroom of a public secondary school in Central Java, and found that the teachers employed the recall type of questions most of the time (52\%). A study in West Sumatra examined the types of questions posed by twelve English, public high school teachers, and classified them using the revised Bloom's taxonomy and the Display-Referential dichotomy. It was found that $53 \%$ of the questions were of Remembering kind, which is at the lowest rung of the taxonomy, and a great majority (83\%) fall under the Display type. Upon further probing through stimulated recall, the teachers revealed that they were limited by the lesson materials and students' cognitive level in giving higher-order thinking questions (Ramadhani \& Zainil, 2019). Interestingly, Mintre and Lie (2020) discovered that a near-native English teacher in a private semi-international school in East Java was able to use mainly HOTS-inducing questions $(65 \%)$ in his class, which seems to suggest that the subject mastery of the teachers and the language competence of students also play a substantial role in the teachers' ability to formulate higher-order thinking questions. This finding led to a new question whether a high level of competence in the language of instruction was required to teach thinking skills. Moreover, no study had been done to compare teachers in different regions in Indonesia in their abilities to employ higher order thinking skills. The study reported in this paper aimed to fill in that research gap.

\section{METHOD \\ Research design}

This research is a case study of teachers of Indonesian Language and English involving both quantitative and qualitative data analysis. This design was chosen in order to gain a comprehensive and in-depth insight into the ability and perception of the fifteen teachers regarding HOTS in the three different regions.

\section{Contexts and participants}

This research is a continuation of a first-year study of secondary school teachers of English and Indonesian Language from five provinces. In this second year of the research, this study focused on 15 (fifteen) teachers in three cities, who have expressed their interest and commitment in participating in this research. There were five teachers of Indonesian Language and ten teachers of English. Below is the description of the city and the list of teachers based on their years of service and places:

City coding: $S$ is a provincial capital and the second largest city in Indonesia, A is the provincial capital of an archipelago province in the Eastern 
part of Indonesia, while $\mathrm{R}$ is a city which is 60 minutes' flight away from the provincial capital on the Eastern part of Indonesia. In simple terms, it can be said that $\mathrm{S}$ is a big city, A is medium, and $\mathrm{R}$ is small.
Teacher coding: IND (Indonesian), ENG (English); 1, 2, etc. are the individual codes for each teacher.

Table 1

List of Participants based on their Subject, Years of Service, and the City

\begin{tabular}{|c|c|c|c|c|}
\hline \multicolumn{5}{|c|}{ Teachers of Indonesian Language } \\
\hline Years of Service & City S & City R & City A & Total \\
\hline Apprentice $(<10$ years $)$ & & R.IND.1 & A.IND.1 & 3 \\
\hline & & & A.IND. 2 & \\
\hline Practitioner (10-15 years) & S.IND.1 & & & 1 \\
\hline Senior $(>15$ years $)$ & S.IND. 2 & & & 1 \\
\hline Total & 2 & 1 & 2 & 5 \\
\hline \multicolumn{5}{|c|}{ Teachers of English } \\
\hline \multicolumn{5}{|c|}{ Apprentice $(<10$ years $)$} \\
\hline & S.ENG.3. & R.ENG. 2. & A.ENG.3 & 3 \\
\hline Practitioner (10-15 years) & S.ENG.4 & R.ENG.3 & A.ENG.4 & 3 \\
\hline Senior $(>15$ years $)$ & S.ENG.5 & R.ENG.4 & 1. A.ENG.5. & 4 \\
\hline Total & & & 2. A.ENG.6. & \\
\hline $\begin{array}{lc}\text { Total } \\
\end{array}$ & 3 & 3 & 4 & 10 \\
\hline $\begin{array}{l}\text { Total Teachers of Indonesian Language and } \\
\text { English }\end{array}$ & 5 & 4 & 6 & 15 \\
\hline
\end{tabular}

\section{Data collection}

To collect the data, the researchers first developed instruments including interview questions, observation instruments, and protocol for the data collection. For the observation instrument, a scoring rubric based on the teaching evaluation form used in the Pendidikan Profesi Guru (Teacher Professional Education) program, or PPG for short, was adapted and modified for this study. The interview questions were developed during the brainstorming sessions of the research team.

The fifteen participants were contacted a few months before the school visit and class observations. All of those contacted gave their signed consents and were informed of the research procedures. They agreed to the whole procedures including writing the lesson plans for the topics in which they would be observed.

A protocol for the classroom observation (available upon request) was developed to inform participants of what they should expect to happen and what they were expected to carry out. On the scheduled observation, the researcher entered the classroom, sat at the back, recorded the learning processes, and took notes based on the observation instrument. Two sets of questions in the classroom observation instrument pertain specifically to the use of higher order thinking skills (HOTS) questioning in the observed class from both the teacher's and the students' perspectives. The researcher gave a grade of 1-10 on each of the items of the observation instruments. For the scoring rubric related to how the teachers promote HOTS in the question formulation in class, it gives the following criteria for the minimum score: "The teacher does not ask questions to the students during the lesson delivery, does not give an opportunity for students to ask questions, answer his/her own question, or does not answer the students' questions". For the maximum score, the rubric states: "The teacher asks HOTS-promoting questions, answers students' questions well, and encourages students to ask." Besides this numerical assessment, the researchers also took field notes in this aspect whenever applicable.

After the classroom observation, each teacher was interviewed for approximately 30 minutes so that the researchers could get a more in-depth insight into the teachers' own perception of their own teaching practice, apart from what was observed in the classroom. The interview was administered on the same day of the observation, immediately after the teachers' classes. Interviews were recorded and then transcribed. Transcripts of the interviews conducted in Indonesian were translated into English. The school visits, observations, and interviews were conducted from April through September 2019.

\section{Data analysis}

This study triangulated the data through different research instruments. The researchers investigated what the teacher participants knew about HOTS and classroom questioning through class observation, using the above-mentioned rubric as the instrument. The data gathered were in the form of teachers' scores as given by the research team. Teachers were also asked their opinions on their teaching practice during the post-observation interviews, which were recorded, transcribed, and coded. The qualitative data were analyzed using the frameworks of Miles 
et al. (2014), while the quantitative-oriented data utilized that of Cohen et al. (2007).

The researchers' scores on teachers' classroom questioning skills were tabulated and analyzed quantitatively using SPSS software. In order to ensure the validity and reliability of the scoring results, two of the research team members scored each teacher in city $\mathrm{R}$. The inter-rater reliability of the two scorers were found to be acceptable ( $\mathrm{r}=$ .70). Qualitative analysis was done on the data collected from the lesson plan analyses and transcripts of the semi-structured interviews. The transcripts were categorized and compiled together into themes. Interpretations of the classroom observation notes and scores were made and compared against lesson plan analyses, pre-test and post-test questions and scores and interview analyses. Ultimately, the researcher's notes on the observed class and the teachers' interview transcripts were coded into related themes to reveal patterns for further interpretation (Miles et al., 2014).

\section{FINDINGS AND DISCUSSION}

Differences in the use of HOTS-promoting questions across the cities, across the different length of service, and across the language medium among the teachers

The first research question to address was whether there are differences in the use of HOTS-promoting questions among the language teachers based on the city they teach in, the length of service, and the language medium. To this effect, the scores from the observation sheets from all the researchers were collected and tabulated, specifically on the rubric that assesses the use of HOTS-promoting questions ("HOTS Questions") in the classroom. The scores were first tabulated according to the city the teachers work in, and the result is in Table 2.

Table 2

The HOTS Question Scores of the Teachers per City

\begin{tabular}{lccccccc}
\hline & \multicolumn{9}{c}{ HOTS Question Score } \\
\cline { 2 - 7 } City & Teacher 1 & Teacher 2 & Teacher 3 & Teacher 4 & Teacher 5 & Teacher 6 & Average \\
\hline City R & 7.50 & 5.50 & 7.00 & 7.00 & NA & NA & 6.75 \\
City A & 6.00 & 6.00 & 8.00 & 8.00 & 8.00 & 6.00 & 7.00 \\
City S & 8.00 & 5.00 & 7.00 & 8.00 & 7.00 & NA & 7.00 \\
\hline
\end{tabular}

A normality test on this data was first performed in SPSS, which yielded a value of $\mathrm{p}=$ 0.138 ( $\mathrm{p}>0.05$ ) with Kolmogorov-Smirnov test. Thus, the data are normally distributed, and a parametric test can be used. Next, one-way Anova was used to determine whether there is a statistically significant difference between the group's means. However, the result showed that there is no significant difference ( $\mathrm{f}(2)=0.077, \mathrm{p}=0.926(\mathrm{p}>$ $0.05)$ ). In other words, there is no statistically significant difference between the average scores of the teachers across the three cities as evaluated by the researchers.

We then tabulated the average score for HOTS Questions across the teachers' years of service. The result can be seen in the table below: A normality test on this data was first performed in SPSS, which yielded a value of $\mathrm{p}=0.138(\mathrm{p}>0.05)$ with Kolmogorov-Smirnov test. Thus, the data are normally distributed, and a parametric test can be used. Next, one-way Anova was used to determine whether there is a statistically significant difference between the group's means. However, the result showed that there is no significant difference ( $\mathrm{f}(2)=$ $0.077, p=0.926(p>0.05))$. In other words, there is no statistically significant difference between the average scores of the teachers across the three cities as evaluated by the researchers.

We then tabulated the average score for HOTS Questions across the teachers' years of service. The result can be seen in Table 3 .

Table 3

The HOTS Question Scores of the Teachers per Years of Service

\begin{tabular}{lccccccc}
\hline & \multicolumn{7}{c}{ HOTS Question Score } \\
\cline { 2 - 8 } City & Teacher 1 & Teacher 2 & Teacher 3 & Teacher 4 & Teacher 5 & Teacher 6 & Mean \\
\hline Apprentice (<10 years) & 7.50 & 7.00 & 6.00 & 8.00 & 8.00 & 7.00 & 7.21 \\
Practitioner (10-15 years) & 7.00 & 6.00 & 8.00 & 5.00 & NA & NA & 6.50 \\
Senior (>15 years) & 5.50 & 8.00 & 7.00 & 8.00 & 6.00 & NA & 7.13 \\
\hline
\end{tabular}

In the same way, the data were first tested for normality and found to follow normal distribution ( $\mathrm{p}$ $=0.051(\mathrm{p}>0.05))$. Running the one-way Anova test gave the following results: $\mathrm{f}(2)=0.648, \mathrm{p}=$ $0.539(p>0.05)$. Therefore, it can be concluded that there is no statistically significant difference between the average scores of the teachers across the years of service.

Lastly, the average score of the HOTS questions between the teachers of Indonesian Language and English were tabulated, as can be seen in Table 4. 
Table 4

Average HOTS Question Scores of the Teachers per Subject

\begin{tabular}{lccccccccccc}
\hline City & T 1 & T 2 & T 3 & T 4 & T 5 & T 6 & T 7 & T 8 & T 9 & T 10 & Mean \\
\hline Indonesian Language & 7.00 & 8.00 & 8.00 & 8.00 & 8.00 & NA & NA & NA & NA & NA & 7.80 \\
English & 7.50 & 5.50 & 7.00 & 6.00 & 6.00 & 8.00 & 6.00 & 5.00 & 7.00 & 7.00 & 6.50 \\
\hline
\end{tabular}

Similarly, we ran a normality test on the data, and this time, the result showed $\mathrm{p}=0.001$ ( $\mathrm{p}>$ $0.05)$, which meant that the data are significantly different from a normal distribution. Therefore, in order to compare the group's means, the Wilcoxon Signed Rank test for non-parametric data was used. The medians of the scores for "Indonesian Language" and "English" were 8.0 and 6.0, respectively. The Wilcoxon Signed-rank test on SPSS shows that there is no significant effect of Group ( $\mathrm{W}=1, \mathrm{Z}=-1.761, \mathrm{p}<0.05, \mathrm{r}=0.078$ ). Therefore, the average score of HOTS questions between the teachers of Indonesian Language and the English teachers are not statistically significant.

Although the statistics did not show a significant difference, the apparently big gap between the average score of the Indonesian Language teachers (7.80) and English teachers (6.50) prompted a deeper investigation into the qualitative aspect of the data. The field notes taken during class observation were reviewed to see how teachers of Indonesian and English used questions in the classroom. It was shown that, in general, English teachers limited their questions to the comprehension check type, such as "Is it clear?" (S.ENG.4) or "Is there any question?" (A.ENG.4). When probed during interviews regarding their reasons for the choice of questions, teacher A.ENG.5 contended, "If I ask higher-order thinking questions, my students will not understand me."

On the other hand, teachers of Indonesian Language were observed to pose questions that triggered students' curiosity or past knowledge. For example, when analyzing a text used in advertising, teacher A.IND.1 asked the students whether they have any personal motto. Teacher S.IND.1 used hypothetical type of questions when she taught procedural text, asking her students to describe the steps to start a motorcycle as a way of reviewing the lesson.

This finding seems to suggest that language medium might be an important factor in the implementation of HOTS in practice. Mintre and Lie's study (2020) found that an English teacher with near-native proficiency was able to engage students in higher-order thinking questions. The fact of the matter, however, is that very few English classrooms in countries where English is regarded as a foreign language have the luxury of teachers with near-native proficiency and students with sufficient English Proficiency. Therefore, there is a need to equip teachers of English with questioning skills and to develop their competence in enhancing students' mastery of English while also engaging them in critical thinking.

Teacher training in questioning skills should also include scaffolding as part of the Vygotsky's education concept "zone of proximal development" or ZPD (1978). In addition to engaging students in collaborative work with the more capable students, teachers should also know how to scaffold and switch from LOT to HOT questions and vice versa to suit students' particular needs. Teachers adjust the level of their questions in response to the learner's level of performance. A study (Nassaji \& Cumming, 2000) on a teacher using ZPD and scaffolding to teach a Farsi speaker English found that as the student improved his English skills, his teacher went from asking yes/no questions to asking questions that required more analytical thinking

\section{What are the perceptions of the language teachers regarding formulating HOTS questions in particular and HOTS in general?}

Pertaining to this research question, the data were taken mainly from the semi-structured interviews conducted after each teacher had finished his/her class. Besides, secondary data such as the lesson plans made by the teachers were also taken into consideration.

During the interview, each teacher was asked the following question among several others: "With the emphasis on HOTS in the current curriculum, what do you think about its implementation in the classroom?" The teachers' lesson plans were checked to see if they contain elements related to HOTS.

The result of the qualitative analysis on the collected data, showing the summary of the interview results and lesson plans' analyses grouped by the cities where the study was conducted, is tabulated in Table 5.

For the Lesson Plan, "Explicit" signifies that HOTS, or some reference to critical thinking in general, is present in the Lesson Plan in one way or another, while "Not Explicit" indicates its absence. Thus, it was revealed that most teachers in city $\mathrm{S}$ were able to show the relation of certain class activity with HOTS or critical thinking. For example, teacher S.ENG.5 indicated in his Lesson Plan that one of his teaching steps, namely grouping students and getting them to identify a family tree, as a 'Creating (C6)' type of activity under HOTS. 
Table 5

Teachers' Perception on HOTS and the Presence of HOTS Elements in the Lesson Plans Grouped per Cities

\begin{tabular}{cll}
\hline City & Teachers' Perception on HOTS as revealed in interviews & HOTS in Lesson Plan \\
\hline R & $\begin{array}{l}\text { Teachers perceive that their students are not capable of HOTS. English teachers } \\
\text { think that it can't be applied in English lessons. }\end{array}$ & Not Explicit \\
A & $\begin{array}{l}\text { The responses range from no clear understanding of HOTS (apprentice teachers) or } \\
\text { trying to implement it a little (a senior teacher), to full understanding of its } \\
\text { principle (a practitioner teacher) }\end{array}$ & Not Explicit \\
Teachers in this city seem to have sufficient understanding of HOTS and have & Explicit \\
& started to apply it in class activities and exam questions
\end{tabular}

Teacher S.IND.2 also identified her teaching activity of getting students to ask questions in response to her material as a 'Critical Thinking' activity in her Lesson Plan.

The following are the extracts of some of the interview responses pertaining to HOTS question:

Teacher R.ENG.3: Maybe they (i.e., the students) can translate [the HOTS question] into Indonesian, so they can answer it correctly. However, when they try to do it in English, HOTS [questions] will be difficult. They're confused.

Teacher A.IND.2: Untuk umumnya, saya belum memahami tentang [HOTS] itu. Tapi menurut saya sepertinya bisa untuk diterapkan di dalam maupun di luar kelas. ("In general, I have not really understood HOTS well. However, in my opinion, it can be applied in and outside the class.")

Teacher S.ENG.4: We have to use methods that can encourage HOTS in the students. For me, I have been doing it through [methods such as] gallery walk and digital story, so they can practice and apply [what they learned].

In sum, teachers in city $\mathrm{R}$ do not display full understanding of HOTS and have a rather pessimistic opinion of its implementation in their classes due to their students' limited language proficiency, echoing the opinions of teachers in the previously cited studies (Ramadhani \& Zainil, 2019;
Seman et al., 2017; Zohar et al., 2001). While in city A, a provincial capital in the eastern part of Indonesia, teachers have begun to have a grasp of HOTS although they may not have practiced it much. Lastly, teachers from City S, which is a provincial capital and the second largest city in Indonesia, seem to have a more positive perception of HOTS and better readiness to engage their students in higher-order thinking skills.

In this sense, our study might be the first to map qualitatively the HOTS' competence of teachers across three different cities of Indonesia and reflect a possible disparity in the teacher training and education regarding HOTS in the country. Doubtless, the vast extent of the archipelago might pose a considerable challenge for the government to provide such training. However, as indicated by a recent study by Khuriyana and Priyono (2020), a collaboration between the Ministry of Villages and a private institution was able to provide digital learning materials with HOTS content to students in a rural part of Eastern Indonesia, with encouraging results. Thus, we might be able to see more positive outcomes if such collaboration is replicated in other remote areas.

The responses of the teachers were also grouped by years of service and the result is tabulated in Table 6.

Table 6

Teachers' Perception on HOTS Grouped per Years of Service

\section{Years of Service}

Apprentice (<10 years)

Practitioner (10-15 years)

Senior (>15 years)

\section{Teachers' Perception on HOTS as revealed in interviews}

They have received some trainings regarding HOTS but have not been able to apply them in class

Except for one teacher in city R, they all have understood the concept of HOTS and applied it in their teaching and exams/quizzes

The responses range from being happy to receive training in HOTS to dissatisfaction about the teachers having to work hard to incorporate HOTS. follows:

Some of the representative comments are as

Teacher A.IND.1 (Apprentice): Kalau untuk pelatihan HOTS masih belum ada dan belum pernah mengikuti, jadi mungkin kekurangannya di situ dan hambatannya di situ. ("There is no HOTS training yet and I have never participated [in such training], so perhaps this is where the weakness and obstacle lie [in order to apply HOTS].”)

Teacher S.IND.1 (Practitioner): Belajar menyelesaikan masalah, mencari solusi, itu kan juga HOTS juga kan. Melatih konstruksi berpikir itu maksudnya cara berpikirnya bagaimana caranya memahami, menganalisa, mengidentifikasi, lalu menemukan solusi permasalahan kan seperti itu. ("Learning how to solve problems is also HOTS, right? Training thinking construction, which means how to think, how to understand, to analyse, to identify, and then finding the solution of the problem, [that is HOTS]")

Teacher R.ENG.4 (Senior): HOTS is something challenging for me in teaching the students here who, on average, are rather deficient in thinking skill. 
As can be expected, the Apprentice teachers were somewhat familiar about HOTS but perhaps have not had sufficient working experience to be able to apply it in their teaching and assessment. Those in the Practitioner group seem to be the most exposed to HOTS training and thus, were confident in applying HOTS methods and principles in class. Lastly, the more senior teachers, though cognizant of HOTS principles, might be rather resistant to change their established teaching practice to include HOTS.

This result differs from the study by Mursyid and Kurniawati (2019) who discovered that the
Baby Boomers teachers, the more senior ones, were most knowledgeable of HOTS and its practice, as compared to their younger counterparts, the Generation X and Y. In any case, it is suggested that teacher training in HOTS targets novice teachers with the more practical aspects of the concept, taps on the enthusiasm and experience of the Practitioner ones, as well as listens to the opinions of the more senior teachers in HOTS' implementation.

Lastly, the interview results containing the teachers' perceptions of HOTS were grouped based on the subject taught, namely Indonesian language and English, as seen below:

Table 7

Teachers' Perception on HOTS Grouped per Subject

\begin{tabular}{ll}
\hline Subject & Teachers' Perception on HOTS as revealed in interviews \\
\hline Indonesian Language & The responses range from having a basic knowledge about HOTS (for the apprentice) to \\
& knowing how to apply and adjust its principle in their teaching (for the practitioner and senior \\
& teachers in city S) \\
& $\begin{array}{l}\text { Except for two practitioner teachers (one from city S and another from city A), generally all } \\
\text { English } \\
\text { English teachers find the application of HOTS difficult for the students or due to constraint in the } \\
\end{array}$
\end{tabular}

Extracts from an Indonesian Language and an English teacher are provided below:

Teacher S.IND.2: Tapi ini, ya itu tadi kan ada mengamati, kan saya minta anak untuk ayo baca dulu, lalu saya minta untuk diskusi, mengeksplorasi, terus mengelompokkan ("Just now there was observation; I asked the students to read first, and then I asked them to discuss, explore, then categorize")

Interviewer: Itu yang Higher Order Thinking itu ya ("That is Higher Order Thinking, right?")

Teacher S.IND.2: Iya. Terus langsung ada tahapantahapannya. Sekarang, itu kerjakan. Kan, itu eksplorasi, asosiasi ya, terus terakhir presentasi dan menyimpulkan. Kan sudah saya laksanakan semua. ("That's right. There are steps; now, do this. That is exploration and association, right? It ended with a presentation and conclusion. I have done everything.")

Teacher A.ENG.5: "For Bahasa Inggris wajib (English as compulsory subject) [the time allocated] is not really enough because how could we engineer or how could we design HOTS for our students with such limited time, but I personally believe, as a creative teacher, I should find the wiser way to make it possible, particularly in reading comprehension."

Thus, similar to the finding related to formulating HOTS questions above, it appears that Indonesian Language teachers are more comfortable and confident in learning about HOTS and applying it in their teaching, as compared to their English counterparts.

\section{CONCLUSION}

This study set out to investigate the ability to formulate HOTS questions by 15 (fifteen) language teachers spread across three different cities of Indonesia, as well as their perception of HOTS' application in their teaching.

In the quantitative analysis, the results yielded no significant difference in the scores pertaining to the ability to formulate HOTS questions of the teachers across the three cities, the years of service, as well as the subject taught. However, the difference between the average score of Indonesian Language teachers (7.8) and English teachers (6.5) prompted a more qualitative review of the field notes taken during class observation, which revealed that English teachers asked more comprehension check type of questions. Thus, language medium might be a meaningful factor affecting the ability of the teachers to formulate HOTS questions.

When asked about their perception of HOTS and its implementation in their classrooms, teachers of City S displayed more knowledge and confidence as compared to their counterparts from the other two cities. It was particularly noted that teachers in City R put forward their students' lack of English proficiency as the reason for not implementing HOTS. The Practitioner teachers also tend to be more conversant and experienced in HOTS, in contrast with the Apprentice and the Senior ones. As can be intuited from the quantitative analysis above, Indonesian Language teachers also tend to fare better in HOTS knowledge and application as compared to the English teachers. All in all, these results shed knowledge on the possible disparity between the different regions in Indonesia with regards to teachers training and education. Thus, it is hoped that HOTS training, or training in critical 
thinking in general, will spread its wings to the more remote regions of the country, as well as focus on giving practical skills to the novice teachers including teachers of English, in order to instill their confidence and in turn their students'.

\section{ACKNOWLEDGEMENT}

This study was funded by a research grant from the Indonesian Ministry of Research, Technology, and the National Research and Innovation Agency. The authors would like to thank their colleague, Trianawaty, S.Pd., M.Hum, for her contributions in data collection of this research.

\section{REFERENCES}

Albergaria-Almeida, P. (2010). Questioning patterns and teaching strategies in secondary education. Procedia - Social and Behavioral Sciences, 2(2), 305-309. https://doi.org/10.1016/j.sbspro.2010.03.096

Anderson, L. W., \& Krathwohl, D. R. (2001). A taxonomy for learning, teaching, and assessing. Longman.

Ariyana, Y., Bestary, R., \& Mohandas, R. (2018). Buku pegangan pembelajaran berorientasi pada keterampilan berpikir tingkat tinggi. Direktorat Jenderal Guru dan Tenaga Kependidikan Kementerian Pendidikan dan Kebudayaan Hak.

Pillay, L. A. M, Omar, A., Raja Harun, R. N. S., \& Zainal, N. (2016). Issues related to the teaching and learning of higher order thinking skills among TESL student teachers. Proceedings of the 1st English Education International Conference, 1(2). 451-456. http://jurnal.unsyiah.ac.id/EEIC/article/view/1 6282

Barak, M., \& Dori, Y. J. (2009). Inservice science teachers via embedded assessment. Journal of Science Teacher Education, 20(5), 459-474. https://doi.org/10.1007/s10972-009-9141-z

Brookhart, S. M. (2010). How to assess higherorder thinking skills in your classroom. ASCD.

Brophy, J. (1988). Research linking teacher behavior to student achievement: Potential implications for instruction of Chapter 1 students. Educational Psychologist, 23(3), 235-286 https://doi.org/10.1207/s15326985ep2303_3

Cotton, K. (1988). Classroom questioning. School Improvement Research Series, 5, 1-22. https://www.ioerdnetwork.com/uploads/2/1/6/3/21631832/k_c otton_classroom_questioning.pdf

Cohen, L., Manion, L., \& Morrison, K. (2017). Research methods in education (8th ed.). Routledge/Taylor \& Francis Group.

Cundale, N. (2001). What we preach? Stated beliefs about communicative language teaching and classroom questioning strategies. The Language Teacher, 25(5), 4-9.

Ennis, R. H. (1985). A logical basis for measuring critical thinking skills. Educational Leadership, 43(2), 44-48. https://doi.org/10.3102/0034654310376953

Fahim, M. (2012). Fostering critical thinking through Socrates' questioning in Iranian language institutes. Journal of Language Teaching and Research. 3(6), 1122-1127. https://doi.org/10.4304/jltr.3.6.1122-1127

Fischer, C., Bol, L., \& Pribesh, S. (2011). An investigation of higher-order thinking skills in smaller learning community social studies classrooms. American Secondary Education, 39(2), 5-26. https://core.ac.uk/download/pdf/217293502.pd f

Harjanto, I., Lie, A., Wihardini, D., Pryor, L., \& Wilson, M. (2018). Community-based teacher professional development in remote areas in Indonesia. Journal of Education for Teaching. International Research and Pedagogy. 44(2), 212-231. https://doi.org/10.1080/02607476.2017.14155 15

Jailani, Sugiman, S., \& Apino, E. (2017). Implementing the problem-based learning in order to improve the students' HOTS and characters. Jurnal Riset Pendidikan Matematika, 4(2), 247-259. https://doi.org/10.21831/jrpm.v4i2.17674

Khuriyana, E., \& Priyono, P. (2020). Akselerasi peningkatan kualitas pendidikan daerah tertinggal melalui model pembelajaran Higher Order Thinking Skill (HOTS) di era industri 4.0 (Studi kasus implemetasi pilot project di Kabupaten Halmahera Barat). PANCANAKA: Jurnal Kependudukan, Keluarga, Dan Sumber Daya Manusia, 1(1), 55-64. https://doi.org/10.37269/pancanaka.v1i1.9

Krathwohl, D. R. (2002). A revision of bloom's taxonomy: An overview. Theory into Practice, 41(4), 212-218. https://doi.org/10.1207/s15430421tip4104_2

Lie, A. (2021). The industrial revolution 4.0 and language education policy: Indonesia readiness to use and democratize English. In F. A. Hamied (Ed.). Literacies, culture, and society towards industrial revolution 4.0: Reviewing policies, expanding research, enriching practices in Asia, (pp. 31-45). Nova Publishers.

Marzano, R. J., Pickering, D. J., \& Pollock, J. E. (2001). Applying the research on instruction: An idea whose time has come. In R. J. Marzano, D. Pickering, \& J. E. Pollock (Eds.). Classroom instruction that works: Researchbased strategies for increasing student 
achievement (pp. 1-10). Association for Supervision and Curriculum Development.

Matra, S. D. (2014). Teacher questioning in classroom interaction. CELT: A Journal of Culture, English Language Teaching \& Literature, 14(1), 82-111. https://doi.org/10.24167/celt.v14i1.58

Miles, M. B., Huberman, A. M., \& Saldana, J. (2014). Qualitative data analysis: A methods sourcebook $\left(3^{\text {rd }}\right.$ ed $)$. Sage Publications.

Mintre, R., \& Lie, A. (2020). Higher order thinking questions in teaching reading in a private primary school. Beyond Words, 8(1), 36-46. https://doi.org/10.33508/BW.V8I1.2092

Miri, B., David, B. C., \& Uri, Z. (2007). Purposely teaching for the promotion of higher-order thinking skills: A case of critical thinking. Research in Science Education, 37(4), 353369. https://doi.org/10.1007/s11165-0069029-2

Mursyid, M., \& Kurniawati, N. (2019). Higher order thinking skills among English teachers across generation in EFL classroom. English Review: Journal of English Education, 7(2), 119-124. https://doi.org/10.25134/erjee.v7i2.1775

Mustika, N., Nurkamto, J., \& Azizah, A. N. (2019). Exploring the Indonesian english teachers' perceptions towards Higher Order Thinking Skills (HOTS) in the 21st century learning. Proceeding of the $2^{\text {nd }}$ International Conference on Future of Education, 2(1), 4651. https://doi.org/10.17501/26307413.2019.2105

Nappi, J. S. (2017). The importance of questioning in developing critical thinking skills. Delta Kappa Gamma Bulletin: International Journal for Professional Educators, 84(1), 30-41. https://cpb-us-

e1.wpmucdn.com/cobblearning.net/dist/6/310 1/files/2018/05/The-Importance-ofQuestioning-2aqkc5j.pdf

Nassaji, H., \& Cumming, A. (2000). What's in a ZPD? A case study of a young ESL student and teacher interacting through dialogue journals. Language Teaching Research, 4(2), 95-121. https://doi.org/10.1191/136216800668619322

Obenchain, K., \& Ives, B. (2006). Experiential education in the classroom and academic outcomes: For those who want it all. Journal of Experiential Education, 29(1), 61-77 https://doi.org/10.1177/105382590602900106

Prihastuti, I., \& Widodo, A. (2019). Teachers understanding about cognitive level on science test items. Journal of Physics: Conference Series, 1157(2), 022054. https://doi.org/10.1088/17426596/1157/2/022054

Ramadhani, R., \& Zainil, Y. (2019). An analysis of teachers' questions in English classroom activity based on HOTS in SMAN Kota Padang. Journal of English Language Teaching 8(4), 2-10.

http://ejournal.unp.ac.id/index.php/jelt/article/ view/106661

Retnawati, H., Djidu, H., Kartianom, Apino, E., \& Anazifa, R. D. (2018). Teachers' knowledge about higher-order thinking skills and its learning strategy. Problems of Education in the 21st Century, 76(2), 215-230. https://dx.doi.org/10.33225/pec/18.76.215

Seman, S. C., Yusoff, W. M. W., \& Embong, R. (2017). Teachers challenges in teaching and learning for higher order thinking skills (HOTS) in primary school. International Journal of Asian Social Science, 7(7), 534545. https://doi.org/10.18488/journal.1.2017.77.53 4.545

Sulaiman, T., Fauzi, A., \& Ayub, M. (2015). Curriculum change in English language curriculum advocates higher order thinking skills and standards-based assessments in Malaysian primary schools. Mediterranean Journal of Social Sciences 6(2), 494-500. https://doi.org/10.5901/mjss.2015.v6n2p494

Sun, Z. (2012). An empirical study on new teacherstudent relationship and questioning strategies in ESL classroom. English Language Teaching, 5(7), 175-183 https://doi.org/10.5539/elt.v5n7p175

Tamah, S. M. (2003). Teacher questions in EFL classes. Seameo Regional Language Centre Singapore.

Thompson, T. (2008). Mathematics teachers' interpretation of higher-order thinking in Bloom's taxonomy. International Electronic Journal of Mathematics Education, 3(2). 96109.

https://www.iejme.com/article/mathematicsteachers-interpretation-of-higher-orderthinking-in-blooms-taxonomy

Tyas, M. A., Nurkamto, J., Marmanto, S., \& Laksani, H. (2019). Developing Higher Order Thinking Skills (HOTS) - Based Questions: Indonesian EFL Teachers' Challenges. Proceeding of the 2nd International Conference on Future of Education, 2(1), 5263. https://doi.org/10.17501/26307413.2019.2106

Vincent-Lancrin, S. Gonzáles-Sancho, C., Bouckaert, M, Luca, F., Fernández-Barrerra, M., Jacotin, G., Urgel, J., \& Vidal, Q. (2019). Fostering students' creativity and critical thinking: What it means in school. Education Research and Innovation, OECD Publishing. https://doi.org/10.1787/62212c37-en

Vygotsky, L. S. (1978). Mind and society: The development of higher psychological processes. Harvard University Press. 
https://doi.org/(Original manuscripts [ca. 1930-1934])

Yu, W. (2010). An analysis of college English classroom questioning. Journal of Language Teaching and Research, 1(2), 136-144 https://doi.org/10.4304/jltr.1.2.136-144
Zohar, A., Degani, A., \& Vaaknin, E. (2001). Teachers' beliefs about low-achieving students and higher order thinking. Teaching and Teacher Education, 17(4), 469-485. https://doi.org/10.1016/S0742051X(01)00007-5 